U. S. DEPARTMENT OF COMMERCE

W. AVERELL HARRIMAN, Secretary

NATIONAL BUREAU OF STANDARDS

E. U. CONDON, Director

\title{
SIZE MEASUREMENTS FOR MEN'S AND BOYS' SHORTS-WOVEN FABRICS
}

\section{COMMERCIAL STANDARD CS137-46}

Effective Date for New Production From Dec. 30, 1946

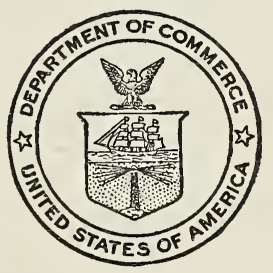

A RECORDED VOLUNTARY STANDARD

OF THE TRADE

UNITED STATES

GOVERNMENT PRINTING OFFICE

WASHINGTON : 1947 


\section{P R O M U L G A T I O N}

of

COMMERCIAL STANDARD CS137-46

for

\section{MEN'S AND BOYS' SHORTS-WOVEN FABRICS}

On October 29, 1945, at the instance of the Underwear Institute, copies of a tentative draft of the proposed commercial standard on size measurements for men's and boys' shorts (made from woven fabrics), was submitted to representative manufacturers, distributors, and users for advance comment and later adjusted to meet the composite recommendations of those concerned.

Since a general conference was deemed unnecessary, the recommended commercial standard was circulated to manufacturers, distributors, and users for written acceptance. Those concerned have since accepted and approved the standard as shown herein for promulgation by the United States Department of Commerce, through the National Bureau of Standards.

The standard is effective for new production from December 30 , 1946.

Promulgation recommended.

F. W. Reynolds, Acting Chief, Division of Trade Standards.

Promulgated.

E. U. Condon,

Promulgation approved.

Director, National Bureau of Standards.

$$
\begin{aligned}
& \text { W. Averell Harrimain, } \\
& \text { Secretary of Commerce. }
\end{aligned}
$$

Project Manager: L. R. Gilbert, Division of Trade Standards.

Technical Adviser: W. D. Appel, Division of Organic and Fibrous Materials. 


\section{SIZE MEASUREMENTS}

FOR

\section{MEN'S AND BOYS' SHORTS-WOVEN FABRICS}

\section{COMMERICAL STANDARD CS137-46}

\section{PURPOSE}

1. The purpose of this commercial standard is to provide standard methods of measuring and standard minimum measurements for men's and boys' shorts, made from woven fabrics, in order to eliminate confusion resulting from a diversity of measurements and methods, and to provide a uniform basis for guaranteeing full size.

\section{SCOPE}

2. This standard covers methods of measuring and standard minimum measurements for boys' shorts and for men's panel back and center seam back shorts, made from woven fabrics. It also includes a recommended label for guaranteeing conformity to the standard.

\section{APPLICATION}

3. The methods and measurements given herein are applicable to finished garments as delivered by the manufacturer.

\section{GENERAL REQUIREMENTS}

4. Method of measuring.-The garment to be measured is laid out without tension on a smooth, flat surface so that creases and wrinkles will not affect the measurements.

5. Accuracy.-Measurements are taken to the nearest one-eighth of an inch.

STANDARD METHODS AND MEASUREMENTS IN DETAIL

METHODS OF MEASURING

SHORTS-MEN'S AND BOYS'

6. Total length.-Measured from top outside edge of waistband to lower outside edge of leg, when garment is buttoned and laid out flat with leg stretched taut. (From A to B, fig. 1.)

7. Thigh.-Measured from bottom of crotch across leg parallel to lower edge of leg to outside edge as garment lies out flat and buttoned. (From C to D, fig. 1.) 
8. Width of waist.-Measured between outside edges of waistband when garment is buttoned and lies out flat. (From A to E', fig. 1.)

9. Leg width.-Measured across leg along lower edge. (From $\mathrm{F}$ to $\mathrm{B}$, fig. 1.)

10. Front rise.-Measured from bottom of crotch including width of seam up front of buttoned garment to middle of front edge of waistband. (From $\mathrm{C}$ to $\mathrm{H}$, fig. 1.)

11. Back rise.-Measured from bottom of crotch not including width of seam up back of buttoned garment to middle of back edge of waistband. (From C to J, fig. 1.)

12. Width across inseam.-Measured from inside corner of one leg to other leg. Legs spread and inseam stretched taut in straight line. (From $\mathrm{G}$ to $\mathrm{C}$ to $\mathrm{F}$, fig. 1.)

13. Front opening. ${ }^{1-}$-Measured from bottom of opening to top edge of waistband. (From K to $\mathrm{H}$, fig. 1.)

14. Width across seat.-Measured across back of buttoned garment at a point $2 \frac{1}{4}$ inches above bottom of $\operatorname{crotch}^{2}$ (table 1 ) for boys' shorts and 3 inches above bottom of crotch (tables 2 and 3 ) for men's shorts. (From $\mathrm{M}$ to $\mathrm{N}$, fig. 1.)

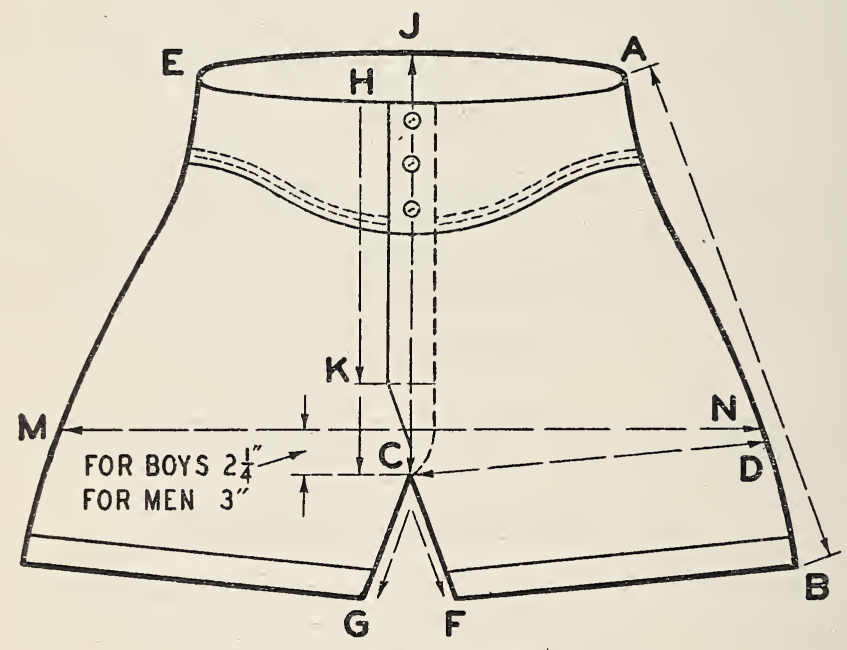

FIGURE 1.--Shorts

STANDARD MINIMUM MEASUREMENTS

15. Standard minimum measurements for boys' shorts are shown in table 1.

16. Standard minimum measurements for men's shorts are shown in tables 2 and 3.

1 Given as a guide only, not as a standard.

2 The crotch is the point from which front and back rise and thigh are measured: 
TABLE 1.-Shorts, boys'-Standard minimum measurements

\author{
U. I. Wov-B1
}

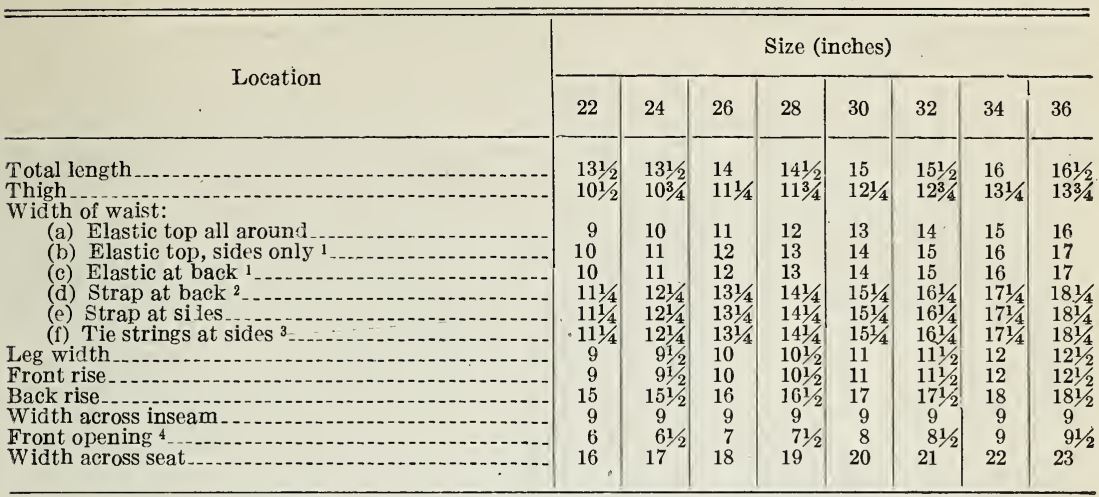

1 The total amount of elastic showing in finished garment at rest shall be not less than 6 inches for each size.

2 Straps shall be so buttoned that all buttonholes on straps are filled with buttons.

3 Ties shall be entirely loosened.

4 Given as a guide only, not as a standard.

TABLE 2.-Shorts, men's panel back-Standard minimum measurements U. I. Wov-M1

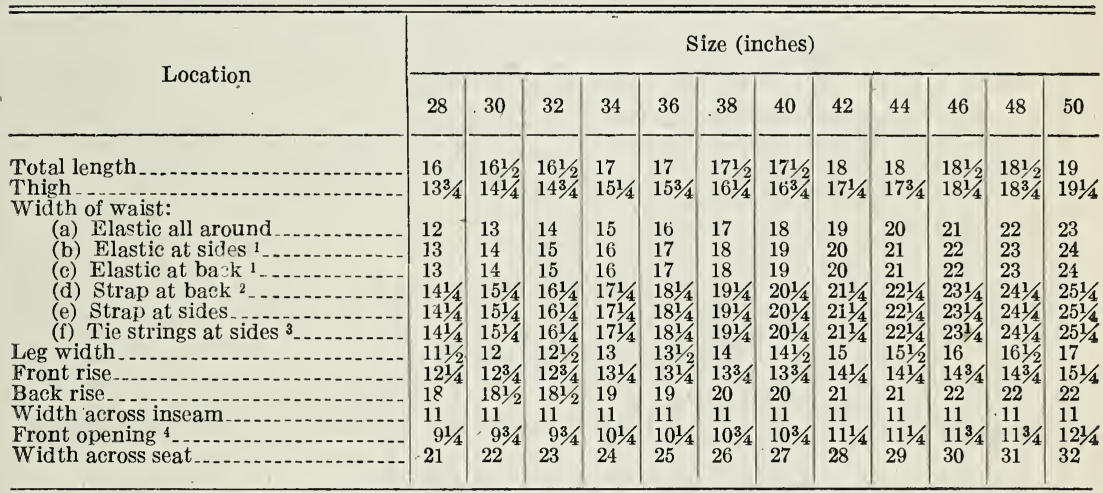

1 The total amount of elastic showing in finished garment at rest shall be not less than 6 inches for each size.

2 Straps shall be so buttoned that all buttonholes on straps are filled with buttons.

3 Ties shall be entirely loosened.

4 Given as a guide only, not as a standard. 
TABLE 3.-Shorts, men's center seam back-Standard minimum measurements

U. I. Wov-M2

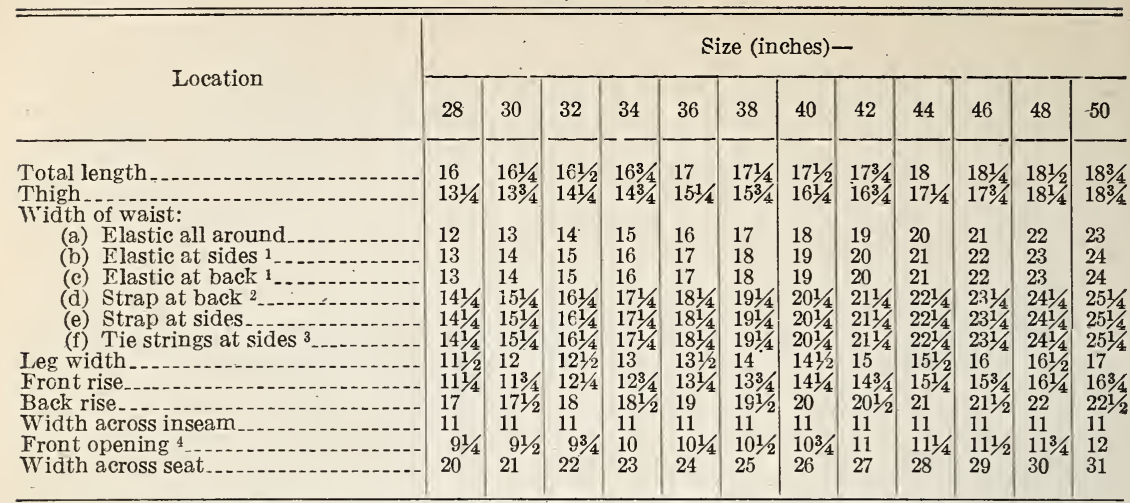

1 The total amount of elastic showing in finished garment at rest shall be not less than 6 inches for each size. 2 Straps shall be so buttoned that all buttonholes on straps are filled with buttons.

3 Ties shall be entirely loosened.

4 Given as a guide only, not as a standard.

\section{LABELING}

17. In order to assure the consumer that he is receiving garments which comply with standard minimum measurements, it is recommended that men's and boys' shorts manufactured to conform to such standard measurements be identified by a sticker, tag, or other label attached to the garment and carrying the following statement:

The manufacturer guarantees this garment to have been made to measurements which are in accordance with Commercial Standard CS137-46, as issued by the National Bureau of Standards, of the United States Department of Commerce.

or more briefly

Size conforms to CS137-46.

\section{EFFECTIVE DATE}

18. The standard is effective for new production from December $30,1946$.

\section{STANDING COMMITTEE}

19. The following individuals comprise the membership of the standing committee, which is to review, prior to circulation for acceptance, revisions proposed to keep the standard abreast of progress. Comment concerning the standard and suggestions for revision may be addressed to any member of the committee or to the Division of Trade Standards, National Bureau of Standards, which acts as secretary for the committee.

Roy A. Cheney, chairman, Underwear Institute, 2 Park Avenue, New York, N. Y.

P. Hubert Hanes, Hanes Knitting Co., Winston-Salem, N. C.

Jerome N. Doumaux, The B. V. D. Corporation, Empire State Building, New York, N. Y.

SoL LEvy, Hansley Mills, Barnesville, Ohio.

T. L. Blanke, National Retail Dry Goods Association, 100 West Thirty-first Street, New York, N. Y. 
Dorothy Ashworth, Montgomery Ward \& Co., 75 Varick Street, New York, N. Y., representing Mail Order Ássociation of America.

George Blount, Woodward \& Lothrop, Eleventh \& F Streets NW., Washington, D. C.

G. Irving BAILY, American Retail Federation, 1627 K Street NW., Washington, D. C.

Mrs. Margaret H. Kingsbury, U. S. Department of the Interior, 2641 West Grand Avenue, Chicago, Ill.

Mrs. Charlotte Payne, National Council of Women of the United States, 501 Madison Avenue, New York, N. Y.

Mrs. E. H. Daniel, Broad Branch and Grant Roads NW., Washington, D. C., representing General Federation of Women's Clubs.

Miss Clara Thropp, President, Professional Woman's League, Inc., 417 East Eighty-fifth Street, New York, N. Y.

\section{HISTORY OF PROJECT}

20. In the latter part of 1933 and the early part of 1934, the Underwear Institute adopted the report of C. H. Hamlin, its Research Associate at the National Bureau of Standards, covering size measurements for men's and boys' shorts made from woven fabrics.

21. On September 6, 1934, for purposes of expediency in connection with the Code of Fair Competition of the Underwear and Allied Products Manufacturing Industry, these data were suspended until September 5, 1935. Since that time they have been available in "Standard Sizes of Knit Underwear" issued by the Underwear Institute.

22. On November 27, 1942, the Office of Price Administration requested the cooperation of the National Bureau of Standards in the establishment of a commercial standard for men's and boys' shorts made from woven fabrics.

23. In order to determine the present status of the measurements included in "Standard Sizes of Knit Underwear," the Underwear Institute in cooperation with the Division of Trade Standards checked with representative members of the industry. The comment received indicated that the industry as a whole was still favorable to the measurements covered in Mr. Hamlin's report of 1933 and 1934.

24. Accordingly, agreeable to the request of the Underwear Institute, the proposed commercial standard on size measurements for men's and boys' shorts-woven fabrics was developed and copies sent to representatives of all concerned, including manufacturers, distributors, and consumers for additional comment and recommendations. In the light of comment received and with the unqualified endorsement of a number of interested organizations, no public hearing was believed necessary.

25. The Recommended Commercial Standard on Size Measurements for Men's and Boys' Shorts-Woven Fabrics, was submitted to the entire trade for written acceptance on March 22, 1946. Having received acceptances in writing estimated to represent a satisfactory majority, announcement was issued on October 30, 1946, that the standard would become effective for new production from December $30,1946$. 

CS137-46

\section{ACCEPTANCE OF COMMERCIAL STANDARD}

If acceptance has not previously been filed, this sheet properly filled in, signed, and returned will provide for the recording of your organization as an acceptor of this commercial standard.

\section{Date}

Division of Trade Standards,

National Bureau of Standards,

Washington 25, D. C.

Gentlemen:

We believe that the Commercial Standard CS137-46 constitutes a useful standard of practice, and we individually plan to utilize it as far as practicable in the

$\begin{array}{llll}\text { Production }^{1} & \text { Distribution }^{1} & \text { Purchase }^{1} & \text { Testing }^{1}\end{array}$

of men's and boys' shorts (made from woven fabrics).

We reserve the right to depart from it as we deem advisable.

We understand, of course, that only those articles which actually comply with the standard in all respects can be identified or labeled as conforming thereto.

Signature of authorized officer

(In ink)

(Kindly typewrite or print the following lines)

Name and title of above officer

Organization

Street address

City, zone, and State

1 Underscore which one. Please see that separate acceptances are filed for all subsidiary companies and affiliates which should be listed separately as acceptors. In the case of related interests, trade associations, trade papers, etc., desiring to record their general support, the words "General support" should be added after the signature. 


\section{TO THE ACCEPTOR}

The following statements answer the usual questions arising in connection with the acceptance and its significance:

1. Enforcement.-Commercial standards are commodity specifications voluntarily established by mutual consent of those concerned. They present a common basis of understanding between the producer, distributor, and consumer and should not be confused with any plan of governmental regulation or control. The United States Department of Commerce has no regulatory power in the enforcement of their provisions, but since they represent the will of the interested groups as a whole, their provisions through usage soon become established as trade customs, and are made effective through incorporation into sales contracts by means of labels, invoices and the like.

2. The acceptor's responsibility.-The purpose of commercial standards is to establish for specific commodities, nationally recognized grades or consumer criteria and the benefits therefrom will be measurable in direct proportion to their general recognition and actual use. Instances will occur when it may be necessary to deviate from the standard and the signing of an acceptance does not preclude such departures; however, such signature indicates an intention to follow the commercial standard where practicable, in the production, distribution, or consumption of the article in question.

3. The Department's responsibility.-The major function performed by the Department of Commerce in the voluntary establishment of commercial standards on a Nation-wide basis is fourfold: first, to act as an unbiased coordinator to bring all interested parties together for the mutually satisfactory adjustment of trade standards; second, to supply such assistance and advice as past experience with similar programs may suggest; third, to canvass and record the extent of acceptance and adherence to the standard on the part of producers, distributors, and users; and fourth, after acceptance, to publish and promulgate the standard for the information and guidance of buyers and sellers of the commodity.

4. Announcement and promulgation.-When the standard has been endorsed by a satisfactory majority of production or consumption in the absence of active, valid opposition, the success of the project is announced. If, however, in the opinion of the standing committee or the Department of Commerce, the support of any standard is inadequate, the right is reserved to withhold promulgation and publication. 


\section{ACCEPTORS}

26. The organizations listed below have individually accepted this standard for use as far as practicable in the production, distribution, testing, or use of men's and boys' shorts. In accepting the standard they reserved the right to depart therefrom as they individually deem advisable. It is expected that articles which actually comply with the requirements of this standard in all respects will be regularly identified or labeled as conforming thereto, and that purchasers will require such specific evidence of conformity.

\section{ASSOCIATIONS}

(General Support)

American Retail Federation, Washington, D. C.

National Council of Women of the United States, New York, N. Y.

National Retail Dry Goods Association, New York, N. Y.

Professional Woman's League, Inc., New York, N. Y.

Southern Garment Manufacturers Association, Inc., Nashville, Tenn.

Underwear Institute, New York, N. Y.

\section{FIRMS}

Abraham \& Straus, Inc., Brooklyn, N. Y.

Ackerman Bros., Elgin, Ill.

Adam, Meldrum \& Anderson Co., Buffalo, N. Y. Aintee Corp., New York, N. Y.

Aldens, Inc., Chicago, Ill.

American Manufacturing Corp., Inc., of New Orleans, New Orleans, La.

Armour-Smallberg, Inc., New York, N. Y

Armstrong-Collier, Inc., Oil City, Pa.

Armstrong \& Co., A. J., New York, N, Y

Askin Brothers Co., Baltimore, Md

Atwood Co., J. J., Upland, Calif.

A very, Thomas W., Clifton, N. J.

B \& B Stores, Inc., Logansport, Ind

B. V. D. Co־p., New York, N. Y.

Ball Stores, Inc., Muncie, Ind.

Bartel Co., Adam H., Richmond, Ind

Baskind \& Co., Inc., H. D., New York, N. Y

Bean \& Son, C. W., Pacolet, S. C

Better Fabrics Testing Bureau, New York, N. Y.

Blatt Co., M. E., Atlantic City, N. J.

Bloomingdale's Department Store, New York, N. Y

Boston Store, Inc., The, Colorado Springs, Colo

Boston Store, Milwaukee, Wis.

Broadway Department Store, Inc., Los Angeles, Calif.

Buffums', Long Beach, Calif.

Butler Brothers, Chicago, Ill.

Carmi-Feature Underwear, Inc., New York, N. Y. Carolina Underwear Co., Inc., Thomasville, N. C. Carson, Pirie, Scott \& Co., Chicago, Ill

Cleland Simpson Co., Scranton, Pa.

Consumers Technical Institute, New York, N. Y.

Coppin Co., Inc., John R., Covington, $\mathrm{Ky}$

Crowley, Milner \& Co., Detroit, Mich

Croyden Shirt Co., Inc., New York, N. Y

D. \& S. Manufarturing Co., Allentown, $\mathrm{Pa}$

Demery \& Co., Detroit, Mich.

Denver Dry Goods Co., Denver, Colo.

Desmond's, Los Angeles, Calif.

E-Z .Mills, Inc., New York, N. Y

Embassy Men's Apparel, Inc., New York, N. Y.

Excelsior Varsity Underwear Corp., New York, N. Y.

Fair, The, Chicago, Ill.

Fandel Co., St. Cloud, Minn.

Gable Co., The Wm. F., Altoona, Pa.

Goodenow Textiles Co., Kansas City, Mo
Gorin Stores, Boston, Mass.

Green United Stores, Inc., New York, N. Y.

Hale Bros. Stores, Inc, San Francisco, Calif.

Halle Bros. Co., The, Cleveland, Ohio.

Hanes Knitting Co., P. H., Winston-Salem, N. C. Hansley Mills, Inc., Paris, Ky.

Harris Co., The, San Bernardino, Calif.

Hart \& Son, L., San Jose, Calif.

Harvard Cooperative Society, Inc., Cambridge, Mass.

Harwood Manufacturing Corp., New York, N. Y.

Hatch Textile Research, New York, N. Y.

Hecht Co., The, Washington, D. C.

Henderson \& Ervin, Charlottesville, Va.

Henes \& Bullwinkel, New York, N. Y.

Higbee Co., The, Cleveland, Ohio.

Higginbotham-Bailey Co., Dallas, Tex.

Hornik \& Co., M., Charleston, S. C.

Howland Dry Goods Co., The, Bridgeport, Conn.

Funter Brothers Co., Inc., Statesville, N. C

Industrial By-Products \& Research Co., Philadelphia, $\mathrm{Pa}$.

Ives, Upham \& Rand Co., Meriden, Conn.

Jahraus Braun Co., Bufialo, N. Y.

Janesville Clothing Co., Janesville, Wis.

Johnston \& Larimer, Inc., Wichita, Kans.

Joslin Co., F. N., Malden, Mass.

Kann Sons Co., S., Washington, D. C.

Kansas, University of, Lawrence, Kans.

Kaufman Store, Inc., The, Richmond, Va.

Keller's Department Store, Liberty, N. Y.

Kirven Co., J. A., Columbus, Ga.

hlein-Norton Co., Los Angeles, Calif.

Krupa, John, Jr., Little Falls, N. Y.

Kugelman's, Woodsville, N. H.

Lasalle \& Koch Co., The, Toledo, Ohio.

Lazarus \& Co., F. \& R., Columbus, Ohio.

Levy Brothers, Burlingame, Calif.

Lit Brothers, Philacielphia, Pa.

Luckey, Platt \& Co., Poughkeepsie, N. Y.

McBratney's Department Store, Monrovia, Calif.

Mac-Wag Manufacturing Co., Gladewater, Tex.

Maison Blanche Co., New Orleans, La.

Manhattan Shirt Co., The, Paterson, N. J.

Mansmann Co., Albert J., Pittsburgh, $\mathrm{Pa}$.

McCro y Stores Corp., New York, N. Y.

Merchants Cash Corp., Boston, Mass.

Miller \& Rhoads, Inc., Richmond, Va.

Milwaukee Boston Store, Inc., Milwaukee, Wis.

Missouri, University of, Columbia, Mo.

Montgomery Ward \& Co., Chicago, Ill.

Moore Dry Goods Co., Harry C., Nevada, Mo.

Munsingwear, Inc., Minneapolis, Minn.

Mylish, Mann \& Drucker, Philadelphia, $\mathrm{Pa}$.

Nantex Manufacturing Co., New York, N. Y.

New Orleans, Inc., Better Business Bureau of, New Orleans, La. (General support).

Outlet Co., Providence, R. I.

Pacific Outfitting Co., Portland, Oreg.

Parke Snow, Inc., Waltham, Mass.

Peck Co., Geo. B., Kansas City, Mo.

Pennsylvania, Commonwealth of, Bureau of Standards, Department of Property \& Supplies, Harrisburg, $\mathrm{Pa}$.

Pincus Co., Joe A., San Antonio, Tex. 
Pomeroy's, Inc., Reading, Pa.

Powers Dry Goods Co., Minneapolis, Minn.

Prange Co., H. C., Green Bay, Wis.

Raleigh Haberdasher, Washington, D. C.

Reis \& Co., Robert, New York, N. Y.

Reliance Manufacturing Co., Chicago, Ill.

Rice-Stix Dry Goods Co., St. Louis, Mo.

Rich's Inc., Atlanta, Ga.

Robinson Manufacturing Co., Inc., Dayton, Tenn.

Saluda Corp., New York, N. Y.

Schoonmaker's, Newburgh, N. Y.

Schudson, Inc., Chas., Milwaukee, Wis.

Schwartz OK Department Store, Anaconda, Mont.

Scranton Better Business Bureau, Scranton, Pa.

(General support).

Seegull Manufacturing Co., Inc., Philadelphia, Pa.

Semel \& Co., Inc., J. H., New York, N. Y.

Sexton Manufacturing Co., Fairfield, Ill:

Shillito Co., John, Cincinnati, Ohio.

Slattery Co., E. T., Boston, Mass.

Snellenburg \& Co., Inc., N., Philadelphia, Pa.

South Dakota State College, Brookings, S. Dak. (General support).

Sperry Co., J. B., Port Huron, Mich.

Steinfeld \& Co., Albert, Tueson, Ariz.

Sterling Stores Co., Little Rock, Ark.

Strawbridge \& Clothier, Philadelphia, Pa.

Superior Co., Inc., New York, N. Y.

swwartz Co., Inc., W. G., Norfolk, Va.
Texas Technological College, Department of Clothing \& Textiles, Lubbock, Tex.

Textron, Inc., New York, N. Y.

Thalhimer's, Richmond, Va.

Topkis Brothers Co., Wilmington, Del.

Traugott Bros., Indianapolis, Ind.

Tyson Shirt Co., Norristown, $\mathrm{Pa}$.

Union Underwear Co., Inc., New York, N. Y.

Utica Knitting Co., Utica, N. Y.

Waite's, Inc., Pontiac, Mich.

Walker's Long Beach, Inc., Long Beach, Calif.

Walker's, San Diego, Calif.

Weinstock, Lubin \& Co., Inc., Sacramento, Calif.

Wickbury, Ltd., New York, N. Y.

Wilson Brothers, Chicago, Ill.

Wise-Smith Co., Inc., Hartford, Conn.

Woodward \& Lothrop, Washington, D. C.

Woolworth Co., F. W., New York, N. Y.

Wright-Metzler Co., U'niontown, $\mathrm{Pa}$

Wurzburg Co., The, Grand Rapids, Mich.

Yoder, Irvin U., Reinerton, $\mathrm{Pa}$.

Ziesel Brothers Co., Elkhart, Ind.

\section{U. S. GOVERNMENT}

Interior, U. S. Department of the, Purchasing Office, Washington, D. C.

War Department, Washington, D. C. 